\title{
NANOCRYSTAlline Thin FilmS AS A MOdel SySTEM FOR SUlfated ZIRCONIA
}

\author{
F.C. Jentoft, A. Fischer, G. Weinberg, U. Wild, R. Schlögl \\ Fritz-Haber-Institut der Max-Planck-Gesellschaft \\ Abteilung Anorganische Chemie \\ Faradayweg 4-6, 14195 Berlin, Germany
}

\section{Introduction and Strategy}

Discovery of the extraordinary activity of sulfated zirconia for $n$-butane isomerization below $373 \mathrm{~K}^{1}$ has led to numerous efforts to investigate and correlate structure, acidity, and reactivity of this material. Although a large data set has been obtained from powdered sulfated zirconia no consistent picture has evolved that satisfactorily describes acidity and reactivity. ${ }^{2}$ In a new approach to better characterize sulfated zirconia we have developed a model system which consists of a nanocrystalline zirconia film supported on silicon.

A preparation procedure for the deposition of various oxide films from aqueous solution has been described in the literature. ${ }^{3}$ A key element in this preparation is the use of a self-assembled monolayer (SAM), an ordered array of long chain surfactant molecules which are anchored to the oxidized surface of a silicon wafer. A sulfonic acid group is then introduced as the functional group at the monolayer-air interface. The SAM-coated wafer is immersed into an aqueous deposition medium, containing zirconium $\left(\mathrm{Zr}^{4+}\right)$, sulfate, and chloride. Within several hours a sulfate containing film consisting of nanosized particles, some of which are tetragonal zirconia, is formed. Calcination at $773 \mathrm{~K}$ produces a predominantly tetragonal $\mathrm{ZrO}_{2}$ film with $2-10$ nm crystals. ${ }^{3}$

We investigated each step of the preparation, using scanning electron microscopy (SEM), atomic force microscopy (AFM) and X-ray photoelectron spectroscopy (XPS), in order to learn how to optimize the preparation procedure for our purposes. We also attempted to identify the mechanism of film growth to be able to tune properties such as film thickness and particle size distribution.

\section{Results and Discussion}

SAM-coated wafers were smooth and homogeneous prior to the oxidation reaction in which the sulfonic acid group was created from the original terminating thioacetate group. A slight roughness - the origin of which is not clarified and may be either contaminants or reactions other than just oxidation of the terminating group - was detected in the sulfonic acid state, and very thin zirconia films deposited on such wafers were modulated with this rough structure, showing that the quality of the SAM is essential.

Deposition conditions given in the literature did not yield zirconia films with optimum properties for our purposes. In a $4 \mathrm{mmol}$

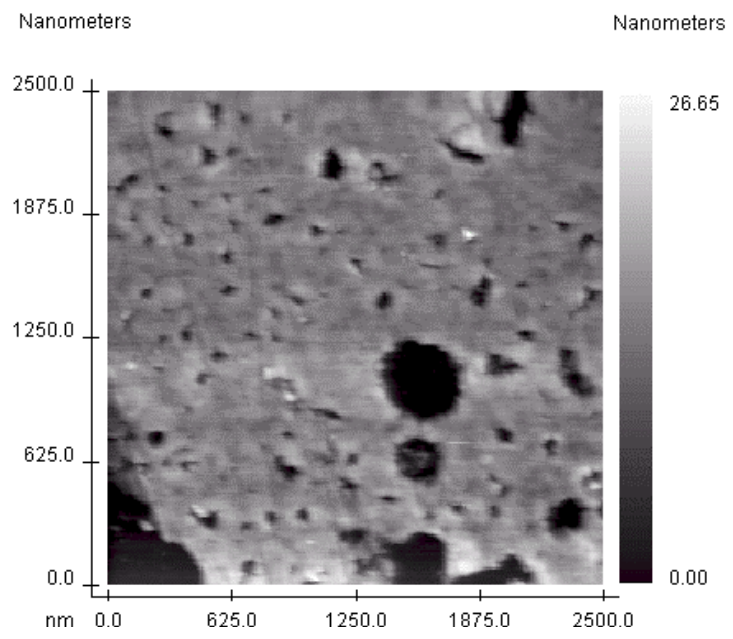

Figure 1: AFM image of a thin zirconia film, deposited at $343 \mathrm{~K}$ from $4 \mathrm{mmol} \mathrm{Zr}\left(\mathrm{SO}_{4}\right)_{2}$ in $0.4 \mathrm{~N}$ $\mathrm{HCl}$, and calcined $2 \mathrm{~h}$ at $773 \mathrm{~K}$ in air $\mathrm{Zr}\left(\mathrm{SO}_{4}\right)_{2} / 0.4 \mathrm{~N} \mathrm{HCl} / \mathrm{H}_{2} \mathrm{O}$ deposition medium colloids and subsequently precipitate formed at $343 \mathrm{~K}$ within $30 \mathrm{~min}$, and such particles and their agglomerates with a size of several $\mu \mathrm{m}$ were embedded into and adsorbed on top of the film surface during the 4-17 hour depositions. 
These particles washed off with water and lab tissues, but patches of film were removed with the particles. ${ }^{4}$ Typical features are shown in Fig. 1. Cracks were observed in uncalcined and calcined films. The number of cracks could be significantly reduced by calcining the films in an inert environment rather than in air.

Particle growth kinetics in the deposition media were investigated and found to be dependent on temperature, and on $\mathrm{Zr}$ and HCl-concentrations. ${ }^{5}$ Film quality improved considerably through deposition at lower temperature; at $323 \mathrm{~K}$ a $4 \mathrm{mmol}$ $\mathrm{Zr}\left(\mathrm{SO}_{4}\right)_{2}$ in $0.4 \mathrm{~N} \mathrm{HCl}$ solution remained clear for 24 hours. Films prepared under these conditions did not exhibit adsorbed particles or holes (Fig. 2) and were mainly crack-free.

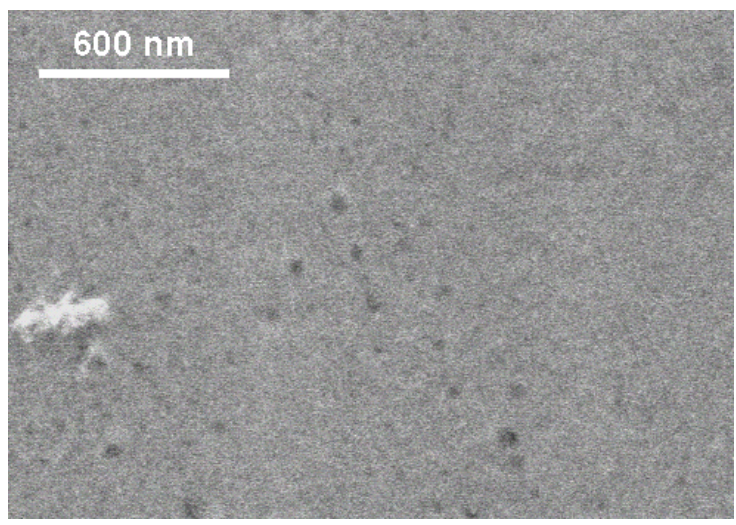

Figure 2: SEM image of a thin zirconia film obtained at $323 \mathrm{~K}$ from a $4 \mathrm{mmol} \mathrm{Zr}\left(\mathrm{SO}_{4}\right)_{2}$ solution in $0.4 \mathrm{~N} \mathrm{HCl}$, and calcined at $773 \mathrm{~K}$ in vacuum

The surface was fairly smooth $\left(A F M: R_{r m s}=1.3 \mathrm{~nm}\right)$. Calcination of the film at $773 \mathrm{~K}$ in vacuum yielded an even smoother surface $\left(R_{\mathrm{rms}}=0.6 \mathrm{~nm}\right)$. A $24 \mathrm{~h}$ deposition produced $12 \mathrm{~nm}$ thick films, and a $48 \mathrm{~h}$ deposition produced $20-40 \mathrm{~nm}$ thick films with $5 \mathrm{~nm}$ tetragonal $\mathrm{ZrO}_{2}$ crystallites (cross-section analysis with transmission electron microscopy). ${ }^{6}$ XPS experiments show an increasing zirconium signal with deposition times of from $15 \mathrm{~min}$ to $24 \mathrm{~h}$; and the substrate signal $(\mathrm{Si})$ was not detected with an uncalcined film grown 24 hours, suggesting a homogeneous coverage. Charging problems in XPS measurements typical for powders were

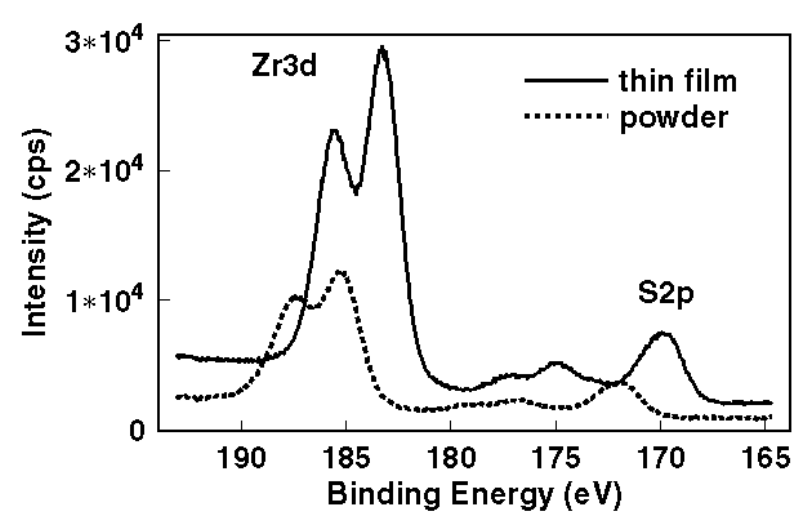

Figure 3: $\mathrm{XP}$ spectra (binding energy only corrected for spectrometer work function) of powdered $\mathrm{Zr}\left(\mathrm{SO}_{4}\right)_{2}$ and a sulfated zirconia film from $24 \mathrm{~h}$ deposition, both treated $1 \mathrm{~h}$ at $773 \mathrm{~K}$ in vacuum reduced with these thin films (Fig. 3).

We are able to prepare sulfatecontaining nanocrystalline zirconia films with properties representative of typical sulfated zirconia catalysts. Use of the films as model system is in progress. The specimens are promising for the collection of ultraviolet PE spectra (UPS) which could yield valuable information on the valence levels of the catalyst as well as the state of adsorbed molecules. Furthermore, the films should be suitable to acquire interpretable temperature-programmed desorption (TDS) data to characterize acid sites.

\section{References}

${ }^{1}$ M. Hino, K. Arata, J. Chem. Soc. Chem. Comm. (1980) 851.

${ }^{2}$ X. Song, A. Sayari, Catal. Rev. - Sci. Eng. 38 (1996) 329.

${ }^{3}$ M. Agarwal, M.R. De Guire, A.H. Heuer, J. Am. Ceram. Soc. 80 (1997) 2967.

4 A. Fischer, F.C. Jentoft, G. Weinberg, R. Schlögl, T.P. Niesen, J. Bill, F. Aldinger, M.R. De Guire, M. Rühle, 5 submitted to J. Mater. Res. 1998.

${ }^{5}$ H. Cölfen, H. Schnablegger, M. Antonietti, A. Fischer, F.C. Jentoft, R. Schlögl, unpublished results.

${ }^{6}$ A.D. Polli, T. Wagner, M. Rühle, A. Fischer, F.C. Jentoft, R. Schlögl, unpublished results. 